\title{
Simultaneous Cranial Subarachnoid Hemorrhage and Spinal Subdural Hematoma
}

\section{Eş Zamanlı Kranial Subaraknoid Kanama ve Spinal Subdural Hematom}

\author{
Ahmet METE ${ }^{1}$, Ibrahim ERKUTLU², Aylin AKCALI ${ }^{3}$, Alper METE ${ }^{4}$ \\ ${ }^{1}$ Gaziantep University, Faculty of Medicine, Department of Radiology, Gaziantep, Turkey \\ ${ }^{2}$ Gaziantep University, Faculty of Medicine, Department of Neurosurgery, Gaziantep, Turkey \\ ${ }^{3}$ Gaziantep University, Faculty of Medicine, Department of Neurology, Gaziantep, Turkey \\ ${ }^{4}$ Gaziantep University, Faculty of Medicine, Department of Ophthalmology, Gaziantep, Turkey
}

Correspondence address: Ahmet METE / E-mail: dr.meteahmet@gmail.com

\begin{abstract}
We report a rare case of simultaneous cranial subarachnoid and spinal subdural hematoma (SDH) in a 42-year-old man who was on Warfarin therapy after cardiac bypass surgery. Computed tomography at presentation revealed a cranial subarachnoid hemorrhage, and spinal Magnetic Resonance Imaging (MRI) showed a spinal SDH extending from the T6 to L5 segments. He had paraparesis due to spinal cord compression. The patient was managed conservatively due to his poor general condition and was infused with intravenous steroid therapy, but he experienced sudden cardiac arrest 5 hours later after being admitted to the hospital. This case is of interest because of its first presentation of spinal subdural hematoma and cranial subarachnoid hemorrhage simultaneously and it is also the second longest vertebral segmental spread in the literature. KEYWORDS: Spinal subdural hematoma, Cranial subarachnoid haemorrhage, MRI, Spinal cord compression
\end{abstract}

öz

Biz bu makalede kardiak by-pass cerrahisi sonrası Warfarin tedavisi alan 42 yaşında erkek bir hastada, eş zamanlı gelişen kranial subaraknoid kanama ve spinal subdural hematom bulgularını bildiriyoruz. Hastanın başvuru kranial bilgisayarlı tomografisinde subaraknoid kanama ve sonrasında yapılan spinal manyetik rezonans görüntülemesinde T6 vertebra düzeyinden başlayıp L5 vertebra düzeyine dek uzanan spinal subdural hematom gözlendi. Hastada spinal kord kompresyonuna bağlı paraparezi mevcut idi. Genel durum bozukluğundan dolayı hasta konservatif olarak intravenöz steroid infüzyon tedavisi ile gözlenirken, hastaneye başvurusundan 5 saat sonra ani kardiak arrest gelişti. Bu olgu literatürde ilk defa eş zamanlı olarak gelişen kranial subaraknoid kanama ve ikinci en uzun segmentte gelişen spinal subdural hematom olması itibariyle ilgi çekicidir.

ANAHTAR SÖZCÜKLER: Spinal subdural hematom, Kranial subaraknoid kanama, MRG, Spinal kord kompresyonu

\section{INTRODUCTION}

Spinal subdural hematomas (SSDH) are rare pathologies which lead to cauda equina syndrome and spinal cord compression. Hemorrhagic disorders, traumas, spinal surgery, lumbar puncture or spinal anesthesia can be the reason of $\operatorname{SSDH}(2,1)$. In addition, spinal vascular malformations or spinal tumors are sometimes reported as the causes of SSDH (5). Diabetes, chronic kidney failure and alcoholism are among the other etiologic reasons. Although the incidence of SSDH is quite low, it can also occur without any risk factors. This kind of SSDH is called "spontaneous spinal subdural hematoma" $(2$, $5,12)$. SSDH is most frequently observed around the thoracal and thoracolumbar regions. Backaches or low-back pains are common among all sufferers as the most frequent symptom (7).

Cranial and spinal subdural hematoma has been reported only in one case previously (6) but to our knowledge simultaneous cranial subarachnoid hemorrhage and spinal subdural hematoma has not reported before in the literature.
In addition, this case had the 2 nd longest vertebral segment extension.

\section{CASE REPORT}

A patient, aged 42 , was admitted to hospital due to sudden head and backaches experienced during sleep. The patient underwent computed brain tomography, which indicated that he had developed subarachnoid hemorrhage. Consequently, the patient was admitted to the intensive care unit. The patient's vital signs were normal but his mood was agitated. Bilateral visual acuities were 1.0 ( $\log$ MAR), eye movements were normal, bilateral direct and indirect light reflexes were positive, and bilateral grade 1 papiledema was observed. Patient cooperation was normal but he was disorientated. He had paraparesis and slight neck stiffness. The patient was reported to have used Warfarin because of a cardiac pacemaker and cardiac by-pass surgery in his past medical history. There was no past medical history of any systemic disease such as ITP (or other blood dyscrasia) causing thrombocytopenia. Computed tomography of the 
patient revealed hyperdense areas in the right frontoparietal region compatible with subarachnoid hemorrhage (Figure 1). Furthermore, MRI of the thoracolumbar region showed an extensive subdural haematoma at the thoracic and lumbar level with compression of the spinal cord (Figure 2, 3). The biochemistry results at this time were as follows: glucose $118 \mathrm{mg} / \mathrm{dl}$, BUN $69 \mathrm{mg} / \mathrm{dl}$, uric acid $7.5 \mathrm{mg} / \mathrm{dl}$, total bilirubin $7.92 \mathrm{mg} / \mathrm{dl}$, direct bilirubin $0.27 \mathrm{mg} / \mathrm{dl}$, AST 194U/L, ALT 53U/L. Complete blood counts were as follows: white blood cells $19600 / \mu \mathrm{L}$, neutrophils $15900 / \mu \mathrm{L}$, hemoglobin $17.7 \mathrm{~g} / \mathrm{dl}$ and thrombocyte count $4800 / \mu \mathrm{L}$. The patient was infused with 30 $\mathrm{mg} / \mathrm{kg}$ methyl prednisolone intravenously in a trauma dose in the first 1 hour, followed by a planned infusion with 5.4 $\mathrm{mg} / \mathrm{kg}$ methyl prednisolone in the next 23 hours. The patient experienced sudden cardiac arrest approximately 5 hours after being admitted to the hospital, resulting in exitus.

\section{DISCUSSION}

Determining the reason of the hemorrhage in the spontaneous SSDH is remarkably difficult and establishing the etiopathogenesis involves considerable effort. Nonspontaneous SSDH occurs secondarily to traumas, lumbar puncture, coagulopathy or anticoagulant drug use, as in this case. Spinal hematomas may be epidural, subdural, subarachnoidal or intraparenchymal. The postulated mechanism that causes non-traumatic spinal subdural hematoma is a sudden increase in the pressure of intraspinal vessels due to indirect reflection of intraabdominal or intrathoracic pressure. This sudden increase in pressure results in ruptures in valveless radiculomedullary veins that cross spinal subdural and subarachnoid spaces. Although the spinal subarachnoid space does not include large veins, Morandi emphasized that thin and delicate extra-arachnoid veins in the inner surface of the dura would lead to subdural

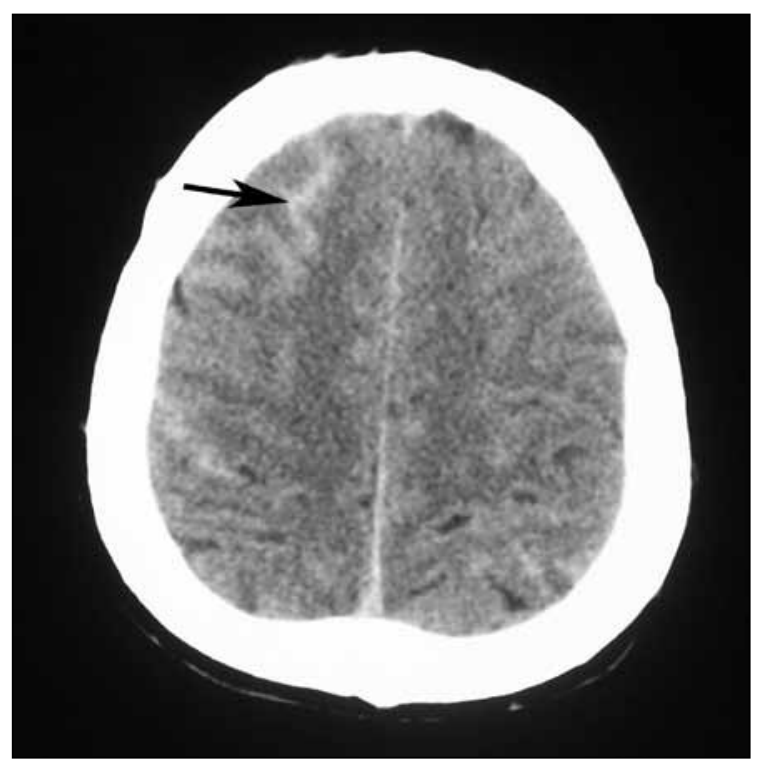

Figure 1: Axial CT section obtained from the convexity level shows hyperdense areas in the right frontoparietal region (black arrow) compatible with the subarachnoid hemorrhage.

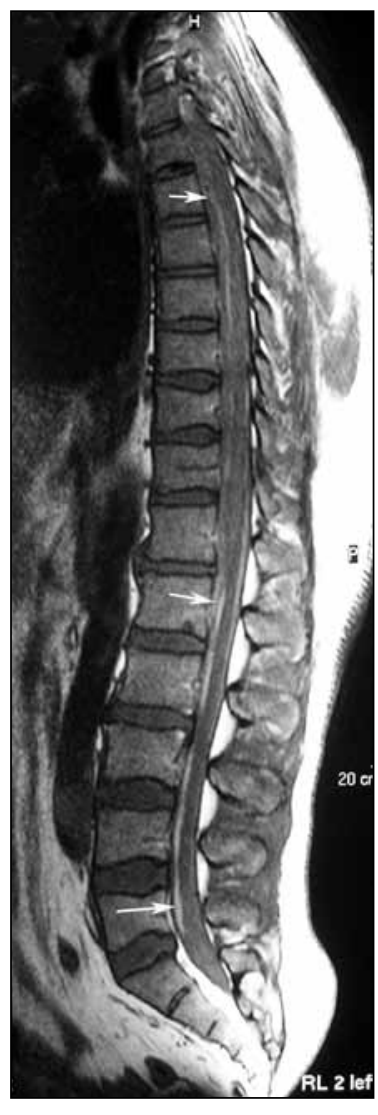

Figure 2: Sagittal T1-weighted MRI image exhibits hyperintense signals related to hematoma extending from T6 to L5 level (white arrows).

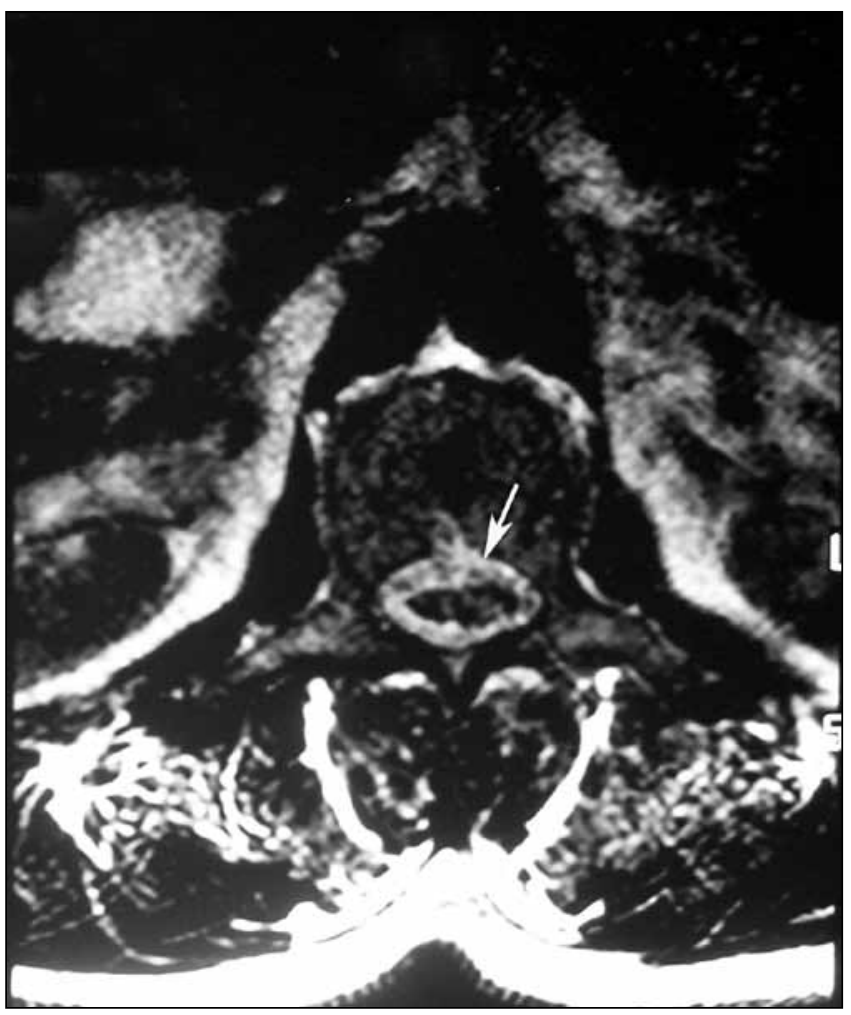

Figure 3: Axial T2-weighted image shows heterogenous hyperintense signal intensity surrounding and compressing the spinal cord at L1 level (white arrow). 
hematoma (11). Secondarily to the increased intrathoracic pressure as a result of minor spinal trauma or sudden physical activity, inner lumen pressures increase in the venous structures located in the subarachnoid area. In the meantime, the sudden decrease in the pressure of cerebrospinal fluid results in laceration of venous structures if it is below intravascular pressure values.

It is not possible to make a distinctive diagnosis in such pathologies through only clinical and neurological examinations or studies. The most significant element of the diagnosis is the MR imaging tool manifesting the size and extension of the hemorrhage as well as its relations with the spinal cord. There are some important and distinctive findings for radiologically distinguishing spinal epidural and subdural hematomas. Spinal epidural hematomas (SEDH) are shorter when compared to SSDH in terms of their craniocaudal extensions (two or four vertebrae), they are biconvex or lentiform shaped, with thinner vertical sides in sagittal images and with regular contours in axial images. Conversely, spinal subdural hematomas appear concaveshaped in sagittal images whereas they exhibit irregular contour in axial images (6). Spinal CT has a more limited role in the diagnosis. As the hemorrhages in spinal CT may show epidural or intradural tumor-like appearances, they may lead to wrong diagnoses (6). If vascular pathology is considered in the diagnosis and immediate surgical decompression is planned subsequently, selective spinal angiography should be done in the preoperative period (3). Spinal epidural and subdural hematomas should be immediately evaluated if the neurosurgical condition of the patient has deteriorated. The initial treatment should consist of a large laminectomy and the evacuation of the hematoma. However, there are cases in the literature which have been treated solely via conservative approaches, without any surgical intervention (6).

In the present case, MRI showed subdural hematoma surrounding the spinal cord between T6-L5 vertebral segments and causing compression. As in the previously reported SSDHs, thoracal areas were reported to be surrounded in the present case, as well (9). It could not be determined through which mechanism(s) the subarachnoid hemorrhage and SSDH developed at the same time. This togetherness or in other words this simultaneity can be accounted for by two scenario. The first is that cranial subarachnoid hemorrhage and SSDH occurred simultaneously. The second is the extension of the cranial SAH to the spinal subdural space by exceeding or lacerating the arachnoid membrane. In the last situation, it is clear that the hemorrhage in the spinal area is of arterial origin.

The anticoagulant therapy itself is often complicated by hemorrhage. Lieberman et al. reported significant hemorrhage in $9.4 \%$ of patients treated with anticoagulants during an 8 year study period. The overall frequency of fatal hemorrhage is $1.0 \%$ (10). Most of the bleeds are minor, involving the genito-urinary or gastrointestinal tract; serious or fatal intracranial bleeds represent the major therapeutic problem. The anticoagulated patient is also jeopardized by the additional risk of spinal bleeding such as epidural and subdural hemorrhage. Once intracranial hemorrhage has occurred during the anticoagulation, medication should be reversed as soon as possible. Patients on anticoagulants for various conditions are always predisposed to bleeding tendencies in spite of a relatively normal coagulation study. A heightened awareness and high index of clinical suspicion should be ascertained in patients who are on chronic anticoagulation therapy.

Thrombocytopenia may also be another factor causing bleeding in CNS. Decreased platelet counts can be due to a number of disease processes such as vitamin B12 or folic acid deficiency, leukemia or myelodysplastic syndrome, decreased production of thrombopoietin by the liver in liver failure, sepsis, systemic viral or bacterial infection, Dengue fever and some hereditary syndromes (4).

Koide et al. studied 96 patients who had hemorrhagic cerebrovascular disease. Among them, only 16 patients (16.7\%) had thrombocytopenia, half of them presented with subarachnoid hemorrhage (SAH), and the remaining showed Intraparenchymal hemorrhage (8).

Etiology of thrombocytopenia in this case may be a systemic or local bacterial infection. There was leukocytosis on $C B C$, and an increase in indirect bilirubin and liver function test results. Prerenal azotemia after infection can be explained by water loss caused by fever or insufficient water intake. The reason the patient died within a short time may have been shock after spinal collapse and internal bleeding due to thrombocytopenia or anticoagulant therapy complicated by hemorrhage. Unfortunately, we could not clarify the actual cause of death and thrombocytopenia as the relatives of the patient did not allow us to perform any diagnostic study or autopsy.

This is the first case of simultaneous SSDH and cranial SAH reported to our knowledge. The longest vertebral extension reported in the literature involves 18 segments, whereas in this patient it was found to be 12 vertebral segments. This is the second longest extension in the craniocaudal axis in the literature (6). In the present case, the hemorrhages of both areas were in the hyperacute- acute phases in terms of radiological age. As a result, as seen from the case report, anticoagulant drug use may lead to simultaneous cranial and spinal hemorrhages whether in the same or in different compartments. In conclusion, we can suppose that the different hemorrhagic events developed in different anatomic compartments but simultaneously, and radiologists and clinicians should be aware of this confusing emergency.

\section{REFERENCES}

1. Barker GL: Spinal subdural hematoma following spinal anaesthesia. Anaesthesia 43:664-665, 1988

2. Domenicucci M, Ramieri A, Ciappetta $P$, Delfini R: Nontraumatic acute spinal subdural hematoma: Report of five cases and review of the literature. J Neurosurg 91:65-73, 1999 
3. Gaitzsch J, Berney J: Spinal subarachnoid hematoma of spontaneous origin and complicating anticoagulation: Report of four cases and review of the literature. Surg Neurol 21:534-538, 1984

4. Gasparetto EL, Benites Filho PR, Davaus T, Carvalho Neto A: Central nervous system hemorrhage in thrombocytopenic patients: Computed tomographic findings in 21 cases. Arq Neuropsiquiatr 65:268-272, 2007

5. Han PP, Theodore N, Porter RW, Detwiler PW, Lawton MT, Spetzler RF: Subdural hematomafroma Type I spinal arteriovenous malformation. Case report. J Neurosurg 90:255-257, 1999

6. Jain V, Singh J, Sharma R: Spontaneous concomitant cranial and spinal subdural haematomas with spontaneous resolution. Singapore Med J 49:e53-58, 2008

7. Khosla VK, Kak VK, Mathuriya SN: Spinal subdural hematomas; Report of two cases. J Neurosurg 63:636-639, 1985
8. Koide K, Manaka S, Takagi K, Kitamura T, Hirakawa M, Sashida J, Nomaguchi S: Clinical significance of thrombocytopenia associated with hemorrhagic cerebrovascular disease. No Shinkei Geka 19:729-734, 1991

9. Kyriakides AE, Lalam RK, El Masry WS: Acute spontaneous spinal subdural hematoma presenting as paraplegia: A rare case. Spine 32:E619-622, 2007

10. Lieberman A, Hass WK, Pinto R, Isom WO, Kupersmith M, Bear G, Chase R: Intracranial hemorrhage and infarction in anticoagulated patients with prosthetic heart valves. Stroke 9:18-24, 1978

11. MorandiX,Riffaud L, ChabertE, Brassier G: Acute nontraumatic spinal subdural hematomas in three patients. Spine 26:E547551, 2001

12. Swann KW, Ropper AH, New PF, Poletti CE: Spontaneous spinal subarachnoid hemorrhage and subdural hematoma. Report of two cases. J Neurosurg 61:975-980, 1984 